\title{
Racism: The Contagious Virus of Human Origin
}

\author{
Emmanuel Chidiebere Edeh* \\ Zhejiang Normal University, China
}

\section{OPINION}

Often, we tend to forget about our own doing or worst, try to excuse ourselves to blame others. This undoubtedly has been the case of the deadliest and the most contagious virus ever know to human beings. Racism like any other virus finds its way to our biological codes and seeks to establish itself. As a virus it alters the normal bio code of the victims to code for itself. For instance, viruses are known to alter the RNA/DNA of their host to code for themselves leaving the host's system weak and susceptible to diseases or other infections. In the same vein, racism virus makes the victims vulnerable to health risks, social and political abuse. Racism cannot be blamed on monkeys and bats or other animals. Racism is of human origin and affects only human beings, as such animals could heave a sigh of relief from human finger pointing.

Racism occurs in many forms: Tribalism, Xenophobia, Segregation, Ethnocentrism, Discrimination, Supremacism, Hatred etc. Depending on the circumstances within which it was exhibited, the feelings and emotions which are attached to its interpretations. Ignorance, fear, and jealousy are often common factors that can trigger racism among people. As rightly stated by Eric Knowles, a psychology professor at New York University who studies politics and prejudice, "Most if not all people carry implicit biases and unexamined prejudices, some may harbour feelings of fear or resentment that they don't express in public". Research reports have also shown that modern variants of racism are often linked to social perceptions of biological differences between peoples. These views according to the reports can take the form of political systems, practices or beliefs, or social actions, in which different races are ranked as inherently superior or inferior to each other, based on presumed shared inheritable traits, abilities or qualities. For instance, there is a misconception about Africans in China by some set of Chinese people. To them Africans are black, lazy, diseased, poor and hungry. Again, a common observation in China where the racial language 黑人 (Hei ren, black person) for a black skinned and 老外 (Laowai, foreigner) for white skinned is used to distinguish foreigners. Or the continuous systematic discrimination against African Americans, Asian Americans, Latinos and other immigrant minorities in US.

Racism is contagious, according to [1] it is often fueled by environment, traditions, culture or societal influence. Like mutation occur viruses, racism in the recent time has taken a more pronounced form. This calls for serious concerns from all sane minds as it seems to be aided by the media outlets, otherwise referred to as Cyber-racism. Again, just like viruses would take advantage of poor hygiene of the people to infect them, racism alike would take advantage of egotism and vanity to infect the minds of human beings. As Abdul Majik Mujahid, an American Muslim Imam, producer author and non-profit entrepreneur stated, "The virus of racism may exist in the hearts and minds of millions around the world but when racism is acted upon, especially by a group of people, things don't just become dangerous, they become deadly". Human affinity to racism is high as it tends to give the racist a sense of apparent self-worth or temporal relief from the feeling of void, while the person at the receiving end is left mentally and physically broken.

The virulent racism can be catastrophic and spares nobody with its aftermath. Racism is relatively linked with the European age of imperialism, colonization of the Americas, Asia, and Africa, Atlantic slave trade, subsequent growth of capitalism, continued Neo- colonization, genocides like the Holocaust, and Rwandan genocide, 20th century apartheid and 21th century xenophobic attacks in South Africa. A report by Abdul Majik Mujahid, estimated that racism in its various forms have been responsible for the death of over 62 million human beings in the last 100 years. Racism impedes economic growth and development; it denies some members the opportunity to participate fully in the scientific and social development of their society and it is toxic to health. Speaking of health risks, researchers at the University of Southern California conducted a small study using the RNA test to explain how racial discrimination raises the risks of disease among African Americans. The results showed that racism appears to increase
Quick Response Code:

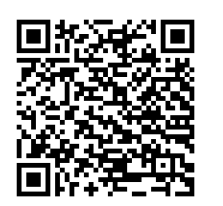

Address for correspondence: Emmanuel Chidiebere Edeh, Zhejiang Normal University, China

Received: May 13, 2020 Published: May 22, 2020

How to cite this article: Emmanuel CE. Racism: The Contagious Virus of Human Origin. 2020 2(3) OAJBS.ID.000171. DOI: 10.38125/OAJBS.000171 
chronic inflammation among African Americans [2]. In the same vein William Wan, a national correspondent covering health, science and news for the Washington post. In his article reported that, experience of discrimination can flood the body with stress hormones such as cortisol- a chemical known to trigger fight or flight response. This stress hormone, over a period can lead to inflammatory reactions that make the body more susceptible to chronic diseases.

Racism has been identified as a threat to peaceful and prosperous world, and overall health risks in Children, adolescents, emerging adults and their family [3]. It robs us the ability to love, tolerate, and harness the best in others. United Nations through its Committee on the Elimination of Racial Discrimination (CERD) has been at the fore-front of promoting understanding among people of races and ensuring the elimination of racial discrimination. NonGovernmental Organizations (NGOs) like American Psychological Association, American Public Health Association, American Academy of Pediatrics etc. Are actively developing remedies and strategies towards ameliorating the menace of racism through their researches and seminars.

Although racism has been widely condemned and different civil rights groups have spun into actions. For instance, as reported by $[4,5]$ in the recent past, when a racist gunman killed 50 people at two mosques in New Zealand and used Facebook platform to post live video of the attack. Facebook took down the video and announced the ban of white nationalist content from its platforms owing to pressures from the civil rights groups. Nevertheless, the recent outplay between the Western media and Chinese media on racist comments due to the outbreak of COVID-19 in China, has not only tested our resolve towards combating racism but also our tendency to gravitate towards racism. To this end, it is pertinent to ask: will there be an end to racism? We all are guilty of racism, for it is of our own making directly or indirectly. In that we all are racist!

As we recognize this menace, it is therefore our collective responsibility at this critical time in our history, to use our resources and platforms to promote understanding among people of races, spread message of love and hope, and ensure the elimination of racial discrimination.

\section{REFERENCES}

1. Wan W, Kaplan S (2017) Why are people still racist? What science says about America's race problem.

2. Science News (2019) Racism has a toxic effect.

3. Trent M, Dooley DG, Dougé J (2019) The impact of racism on child and adolescent health.

4. Stack L (2019) Facebook announces new policy to ban white nationalist content.

5. Abdul MM (2016) Racism statistics and facts. 